\title{
Diagenetic control of nitrogen isotope ratios in Holocene sapropels and recent sediments from the Eastern Mediterranean Sea
}

\author{
J. Möbius, N. Lahajnar, and K.-C. Emeis \\ Institute of Biogeochemistry and Marine Chemistry, University of Hamburg, Bundesstr. 55, 20146 Hamburg, Germany \\ Received: 4 February 2010 - Published in Biogeosciences Discuss.: 17 February 2010 \\ Revised: 29 June 2010 - Accepted: 15 November 2010 - Published: 30 November 2010
}

\begin{abstract}
The enhanced accumulation of organic matter in Eastern Mediterranean sapropels and their unusually low $\delta^{15} \mathrm{~N}$ values have been attributed to either enhanced nutrient availability which led to elevated primary production and carbon sequestration or to enhanced organic matter preservation under anoxic conditions. In order to evaluate these two hypothesis we have determined $\mathrm{Ba} / \mathrm{Al}$ ratios, amino acid composition, $\mathrm{N}$ and organic $\mathrm{C}$ concentrations and $\delta^{15} \mathrm{~N}$ in sinking particles, surface sediments, eight spatially distributed core records of the youngest sapropel S1 (10-6 ka) and older sapropels (S5, S6) from two locations. These data suggest that (i) temporal and spatial variations in $\delta^{15} \mathrm{~N}$ of sedimentary $\mathrm{N}$ are driven by different degrees of diagenesis at different sites rather than by changes in $\mathrm{N}$-sources or primary productivity and (ii) present day TOC export production would suffice to create a sapropel like S1 under conditions of deepwater anoxia. This implies that both enhanced TOC accumulation and ${ }^{15} \mathrm{~N}$ depletion in sapropels were due to the absence of oxygen in deep waters. Thus preservation plays a major role for the accumulation of organic-rich sediments casting doubt on the need of enhanced primary production for sapropel formation.
\end{abstract}

\section{Introduction}

In the Eastern Mediterranean Sea (EMS) paleoceanographic record, the ratio of stable $\mathrm{N}$ isotopes ${ }^{15} \mathrm{~N} /{ }^{14} \mathrm{~N}\left(\delta^{15} \mathrm{~N}\right)$ of organic-rich sediment layers (sapropels) has been very influential in the debate about conditions leading to past black shale formation in a region which is at present an extreme nutrient desert. In a commonly accepted model, recurrent

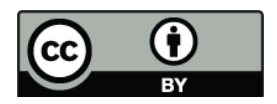

Correspondence to: J. Möbius

(juergen.moebius@zmaw.de)
Mediterranean sapropel formation is attributed to a stratified water column and anoxic deep water conditions that developed as a consequence of enhanced fresh water inputs (Ryan, 1972; Rossignol-Strick et al., 1982; Rohling, 1994; Emeis et al., 2000). The youngest sapropel - termed S1 - formed between 9800 and 5700 years ago (de Lange et al., 2008) at water depths below $400 \mathrm{~m}$ (Anastasakis and Stanley, 1986) with inferred deep-water anoxia everywhere below $1800 \mathrm{~m}$ water depth (de Lange et al., 2008). The sedimentary total organic carbon (TOC) concentration reaches more than $30 \%$ in some Pliocene sapropels (Emeis et al., 1996) and is approximately 2\% in S1 (Murat and Got, 2000). Presentday pelagic surface sediments have a range of TOC content of $0.2-0.6 \%$ only (see below). The higher TOC content (which is associated with faunal, floral, and geochemical changes) of sapropels has been attributed to either greatly enhanced surface productivity, which would suggest a different nutrient regime compared to recent conditions (Calvert et al., 1992; Kemp et al., 1999; Mercone et al., 2001), or to a better preservation of organic matter under oxygen-deficient bottom-water conditions at approximately equal productivity rates (Cheddadi and Rossignol-Strick, 1995; Sachs and Repeta, 1999; Moodley et al., 2005) or some combination of both. Based on stoichiometric calculations, several authors recently proposed that there is a causal link between anoxia and enhanced productivity via the enhanced recycling of phosphate from sediments/and sinking particles in the water column under anoxic conditions increasing $\mathrm{N}_{2}-$ fixation (Tyrrell, 1999; Wallmann, 2003). This model combines increased productivity during S1 deposition with enhanced preservation (Struck et al., 2001; Slomp et al., 2002; Arnaboldi and Meyers, 2006; Emeis and Weissert, 2009).

A key argument for this hypothesis is derived from low values of $\delta^{15} \mathrm{~N}$ in all sapropels, ranging from $-5.1 \%$ o to $2 \%$ whereas surrounding hemipelagic sediments that are poor in organic carbon always have $\delta^{15} \mathrm{~N}>4 \%$ (Milder and

Published by Copernicus Publications on behalf of the European Geosciences Union. 


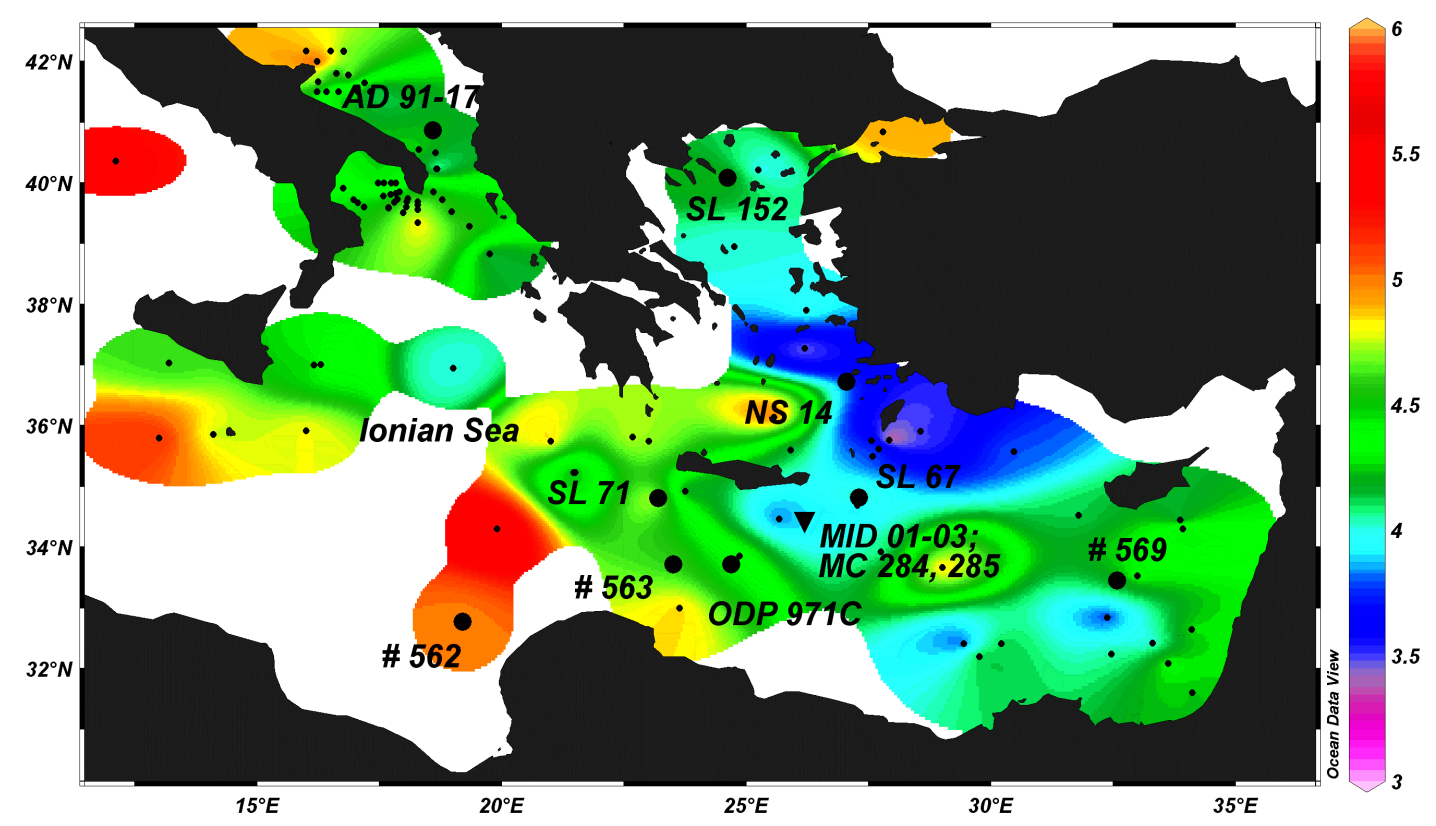

Fig. 1. Sampling sites in the Eastern Mediterranean Sea. Large dots: sediment cores; Triangle: Ierapetra Deep sediment traps and multicores; small dots: surface sediment samples. The color shading is $\delta^{15} \mathrm{~N}(\%)$ in surface sediments based on this study and Struck et al. (2001). The map is produced by using Ocean Data View (Schlitzer, 2009).

Montoya, 1999; Struck et al., 2001; Meyers and Bernasconi, 2005; Arnaboldi and Meyers, 2006). The $\delta^{15} \mathrm{~N}$ in nonsapropel sediments thus are similar to pelagic sediments world wide that range from 5 to $15 \%$ o (Holmes et al., 1996; Holmes et al., 1997; Gaye-Haake et al., 2005). The $\delta^{15} \mathrm{~N}$ of sediments integrates the isotopic composition of the assimilated nitrate source, biological fractionation, foodweb dynamics, and isotope fractionation during sediment diagenesis (McClelland and Valiela, 1998; Voss et al., 2005; Altabet, 2007; Fry, 2007; Dähnke et al., 2008). As a paleoceanographic tool, $\delta^{15} \mathrm{~N}$ is widely used to reconstruct the reactive nitrogen regime of the oceans over geological time scales (Farrell et al., 1995; Jenkyns et al., 2001; Ganeshram et al., 2002; Kuypers et al., 2004; Altabet, 2007; Garvin et al., 2009).

The fact that $\delta^{15} \mathrm{~N}$ values in sapropels are lower than in the surrounding hemipelagic carbonate-rich muds has been attributed to incomplete assimilation of nitrate and concomitant preferential ${ }^{14} \mathrm{~N}$ uptake, implying excess nitrate and enhanced reactive $\mathrm{N}$ supply by either river discharge or upwelling into the photic zone (Calvert et al., 1992). Other authors attributed massive addition of fixed nitrogen to intense P-recycling from anoxic sediments (Struck et al., 2001), or to a compensation for nitrate loss by denitrification at suboxic interfaces between surface and deep waters (Arnaboldi and Meyers, 2006). Interestingly, present-day suspended matter, sinking particles and deep-water nitrate in the EMS all have light $\delta^{15} \mathrm{~N}$ similar to the $\delta^{15} \mathrm{~N}$ of sapropel S1. Assuming that this indicates significant $\mathrm{N}_{2}$-fixation in the modern EMS,
Sachs and Repeta (1999) proposed that the S1-situation was similar to the present-day situation, and that the low $\delta^{15} \mathrm{~N}$ in $\mathrm{S} 1$ is due to the preservation of the original $\delta^{15} \mathrm{~N}$ signature of sedimenting newly fixed N. Preservation may play an important role because sedimentary $\delta^{15} \mathrm{~N}$ is known to become enriched during $\mathrm{OM}$ degradation resulting from preferential loss of ${ }^{15} \mathrm{~N}$ depleted compounds (Altabet, 1996; Freudenthal et al., 2001; Gaye-Haake et al., 2005). Although exact mechanisms remain unknown, kinetic isotope fractionation during protein hydrolysis (Bada et al., 1989; Silfer et al., 1992) and deamination (Macko and Estep, 1984) very likely cause this enrichment.

The recent EMS nutrient and productivity regime appears to be an improbable setting for black shale (also known as sapropel) deposition, even if preservation of OM was enhanced by anoxia. The EMS presently has a highly oligotrophic nutrient regime where the carbon export flux $\left(\mathrm{gC} \mathrm{m}^{-2} \mathrm{a}^{-1}\right.$; Bethoux, 1989) is half of that of the Sargasso Sea. However, both modes of the EMS (the modern nutrient desert and the sapropel mode) have $\delta^{15} \mathrm{~N}$ values lower than the global average. As shown in Fig. 1, surface sediments in the EMS presently have $\delta^{15} \mathrm{~N}$-values between $5 \% 0$ and 3.5\%o with an eastward decreasing gradient. This is explained by either preferential assimilation of ${ }^{14} \mathrm{NO}_{3}^{-}$(Struck et al., 2001) caused by an excess of nitrate over phosphate in surface waters of the EMS (Krom et al., 2005), or by an eastward increasing supply of fixed N (Pantoja et al., 2002). Although until recently fixed $\mathrm{N}_{2}$ was the strongest candidate to explain the low modern $\delta^{15} \mathrm{~N}$ levels, the observational 
evidence for significant diazotrophic $\mathrm{N}_{2}$ fixation is scarce and ambiguous (Mara et al., 2009) and the biogeochemical need is questionable (Krom et al., 2010). New data on the $\delta^{15} \mathrm{~N}$ of $\mathrm{NO}_{\mathrm{x}}$ input from the atmosphere suggest that the present-day $\mathrm{N}$-cycle of the EMS may not be an analogue of pre-anthropogenic conditions: $\delta^{15} \mathrm{~N}$ in nitrate in both dry and wet atmospheric deposition samples have consistently negative $\delta^{15} \mathrm{~N}$ compared to air $\mathrm{N}_{2}$, implying a strongly ${ }^{15} \mathrm{~N}$ depleted atmospheric source that contributes $>50 \%$ of external nitrate inputs with a weighted annual $\delta^{15} \mathrm{~N}$ of $-3.1 \%$ o (Mara et al., 2009). These authors propose that assimilation of the ${ }^{15} \mathrm{~N}$-depleted atmospheric nitrate in the surface mixed layer and subsequent particle flux and mineralisation in the deep water over the last 40-50 years accounts for the unusually low $\delta^{15} \mathrm{~N}$ ratios found in deep-water $\mathrm{NO}_{3}^{-}$without the need of any significant $\mathrm{N}_{2}$ fixation. The nitrogen cycle in the EMS of today thus is not likely to be in a natural state, and the similarity of modern and $\mathrm{S} 1 \delta^{15} \mathrm{~N}$ values is due to the fact that the dominant anthropogenic source today $\left(\delta^{15} \mathrm{~N}=-3.1 \%\right.$ ) and the postulated $\mathrm{N}_{2}$-fixation source during $\mathrm{S} 1$ ( -2 to $1 \%$; Minagawa and Wada, 1986) produce similarly ${ }^{15} \mathrm{~N}$ depleted sedimentary $\delta^{15} \mathrm{~N}$ values.

But what information then do the low $\delta^{15} \mathrm{~N}$ values in $\mathrm{S} 1$ sediments hold with regard to input and cycling of reactive $\mathrm{N}$ during sapropel deposition? As with any proxy, it is essential that the signal encoded in $\delta^{15} \mathrm{~N}$ is not affected by syn- and post-depositional alterations, or that the diagenetic influence is known and can be corrected for. An overriding control appears to be the bottom water oxygenation that drives OM-remineralization and concomitant ${ }^{15} \mathrm{~N}$ enrichment (Saino and Hattori, 1980; Altabet, 1988; Sachs and Repeta, 1999). Sachs and Repeta (1999) already determined a pristine $\delta^{15} \mathrm{~N}$ of eastern Mediterranean sediments that has been preserved in non-altered chlorins and suggest an early diagenetic enrichment of 5.7\% in non-sapropel sediments. Higgins et al. (2010) refined this approach, but found no diagenetic enrichment in non-sapropels. Further studies in other regions of the world ocean detected pristine $\delta^{15} \mathrm{~N}$, not affected by early diagenetic enrichment in diatom frustules (Sigman et al., 1999) and foraminifer shells (Ren et al., 2009).

In the case of the EMS and S1, data shown in (Moodley et al., 2005) already suggested strong post-depositional relative enrichment in $\delta^{15} \mathrm{~N}$ (by 4-5\%o) associated with continued and progressive re-oxygenation of the uppermost section of the S1 sapropel ("burndown"). This appears to be a pervasive feature when the bottom waters became oxic after sapropel formation and additionally compromises the reliability of $\delta^{15} \mathrm{~N}$ as a proxy for the original environment with low sedimentation rates such as the Mediterranean Sea (Jung et al., 1997).

The aim of this study is to quantify the mechanisms influencing $\delta^{15} \mathrm{~N}$ during $\mathrm{S} 1$ sapropel deposition and to identify suspected syn- and post-depositional alteration. This is possible by using paired data of $\delta^{15} \mathrm{~N}$ and an index of or- ganic matter preservation based on amino acid composition. At the same time we discuss the possible impact of changes in preservation on other proxies, such as total organic carbon and nitrogen contents, as well as the $\mathrm{Ba} / \mathrm{Al}$ ratio (indicative for biological productivity; Dymond et al., 1992; Francois et al., 1995). To decide if the isotopic signature is more related to diagenesis/preservation or reflects the nutrient regime at the sea surface (including sources, availability and utilization of nitrate), we examined the S1 sapropel time slice at six locations in different basins and at different water depths of the EMS. Data from sinking material intercepted by sediment traps and surface sediments of the modern EMS are also examined for the impact of early diagenetic alterations on $\delta^{15} \mathrm{~N}$ during particle sinking and at the sediment surface. These data and additional data from the Pleistocene S5 and S6 sapropels enable us to distinguish between time slice specific and general tendencies in the behavior of $\delta^{15} \mathrm{~N}$. Specifically, they permit us to answer the following questions: is $\delta^{15} \mathrm{~N}$ signal in sapropels closely linked to preservation? Were there geographical gradients in $\delta^{15} \mathrm{~N}$ during $\mathrm{S} 1$ sapropel times, and were these gradients the same as today?

\section{Methods}

Sinking particulate nitrogen (SPN) has been collected at the MID-station (Mediterranean Ierapetra Deep) by sediment traps during a series of three to seven months periods from early 1999 to summer 2007. The traps used in this study were Mc Lane Mark VII and Kiel K/MT 234 type with a collection area of $0.5 \mathrm{~m}^{2}$. Sampling intervals varied between 3.5 and 14 days, and the traps were deployed in water depths between $1508 \mathrm{~m}$ and $2720 \mathrm{~m}$. Detailed information about trap position, depth and sampling intervals is given in Table 1.

Sediment samples were taken during Meteor cruises $M$ 40/4, M 44/4, M 51/3 as well as RV Minerva AD91 cruise (Giunta et al., 2003) and RV Aegeo cruise (Triantaphyllou et al., 2009) as multicores and gravity cores. ODP $971 \mathrm{C}$ is an Ocean Drilling Program core recovered during Leg 160. Further details are given in Table 2. Core locations and the sediment trap deployments are shown in Fig. 1, superimposed are contours of present-day surface sediment $\delta^{15} \mathrm{~N}$ in \%o.

\subsection{Analytical methods: organic carbon and nitrogen}

Total carbon, organic carbon and total nitrogen were measured in duplicate by a Carlo Erba 1500 CNS Analyser (Milan, Italy). The precision of this method is $0.01 \%$ for total carbon and $0.002 \%$ for nitrogen. Organic carbon was analysed after removal of $\mathrm{CaCO}_{3}$ by $1 \mathrm{~N}$ hydrochloric acid (three times) with a precision of $0.02 \%$. 
Table 1. Sediment trap moorings in the Ierapetra Deep: position, water depth, sampling depth, deployment period and trap type.

\begin{tabular}{lcccccl}
\hline Mooring & $\begin{array}{c}\text { Longitude } \\
\left({ }^{\circ} \mathrm{E}\right)\end{array}$ & $\begin{array}{c}\text { Latitude } \\
\left({ }^{\circ} \mathrm{N}\right)\end{array}$ & $\begin{array}{c}\text { Water depth } \\
(\mathrm{m})\end{array}$ & $\begin{array}{c}\text { Sampling depth } \\
(\mathrm{m})\end{array}$ & $\begin{array}{c}\text { Deployment period } \\
\text { dd.mm.yy }\end{array}$ & Trap type \\
\hline MID 01 & 26.1792 & 34.4317 & 3750 & 2720 & $30.01 .99-13.04 .99$ & Mark VII \\
MID 02 & 26.1900 & 34.4417 & 3600 & 2560 & $05.11 .01-01.04 .02$ & Mark VII \\
MID 03 SH & 26.1930 & 34.4438 & 3620 & 1508 & $30.01 .07-22.08 .07$ & Mark VII \\
MID 03 DP & 26.1930 & 34.4438 & 3620 & 2689 & $30.01 .07-22.08 .07$ & Kiel K/MT 234 \\
\hline
\end{tabular}

Table 2. Sediment sampling locations and sample types: $\mathrm{MC}=$ Multicore, $\mathrm{GC}=$ Gravity Core, $\mathrm{ODP}=$ Ocean Drilling Program Core.

\begin{tabular}{llllll}
\hline Cruise & Core & $\begin{array}{l}\text { Core } \\
\text { type }\end{array}$ & $\begin{array}{l}\text { Long. } \\
\left({ }^{\circ} \mathrm{E}\right)\end{array}$ & $\begin{array}{l}\text { Lat. } \\
\left({ }^{\circ} \mathrm{N}\right)\end{array}$ & $\begin{array}{l}\text { Water depth } \\
(\mathrm{m})\end{array}$ \\
\hline M 51/3 & \# 562 & MC & 19.191 & 32.774 & 1390 \\
M 51/3 & \# 563 & MC & 23.499 & 33.718 & 1881 \\
M 51/3 & \# 569 & MC & 32.576 & 33.452 & 1294 \\
M 51/3 & SL 152 & GC & 24.611 & 40.087 & 978 \\
M 40/4 & SL 67 & GC & 27.296 & 34.814 & 2158 \\
M 40/4 & SL 71 & GC & 23.194 & 34.811 & 2788 \\
M 44/4 & MC 284 & MC & 26.097 & 34.415 & 4263 \\
M 44/4 & MC 285 & MC & 26.179 & 34.432 & 3702 \\
RV Ageo & NS 14 & GC & 27.047 & 36.725 & 505 \\
RV Minerva & AD 91-17 & GC & 18.586 & 40.870 & 844 \\
ODP 160 & ODP 971C & ODP & 24.683 & 33.717 & 2141 \\
\hline
\end{tabular}

\subsection{Stable nitrogen isotopic ratio $\left(\delta^{15} \mathrm{~N}\right)$}

The ratio of the two stable isotopes of nitrogen $\left({ }^{15} \mathrm{~N} /{ }^{14} \mathrm{~N}\right)$ is expressed as $\delta^{15} \mathrm{~N}$ :

$\delta^{15} \mathrm{~N}(\% \circ)=\frac{\left(R_{\text {sample }}-R_{\text {standard }}\right)}{R_{\text {standard }}} \cdot 1000 \quad R=\frac{{ }^{15} \mathrm{~N}}{{ }^{14} \mathrm{~N}}$

The standard is atmospheric $\mathrm{N}_{2}$, defined as $\delta^{15} \mathrm{~N}=0 \%$.

$\delta^{15} \mathrm{~N}$ values were determined using a Finnigan MAT 252 gas isotope mass spectrometer after high-temperature flash combustion in a Carlo Erba NA-2500 elemental analyzer at $1100{ }^{\circ} \mathrm{C}$. Pure tank $\mathrm{N}_{2}$ calibrated against the reference standards IAEA-N-1 and IAEA-N-2 of the International Atomic Energy Agency and a sediment standard was used as a working standard. $\delta^{15} \mathrm{~N}$ is given as the per mil deviation from the $\mathrm{N}$-isotope composition of atmospheric $\mathrm{N}_{2}$. Analytical precision was better than $0.1 \%$ based on replicate measurements of a reference standard. Duplicate measurements of samples resulted in a mean standard deviation of $0.19 \%$.

\subsection{Amino acids}

Total hydrolysable amino acids were analysed with a Biochrom 30 Amino Acid Analyser after hydrolysis of 3$40 \mathrm{mg}$ of sediments with $6 \mathrm{~N} \mathrm{HCl}$ for $22 \mathrm{~h}$ at $110^{\circ} \mathrm{C}$. Af- ter separation with a cation exchange resin, the individual monomers were detected fluorometrically. Duplicate analysis according to this method results in a relative error of $4 \%$ for total AA. Further analytical details are given elsewhere (Jennerjahn and Ittekkot, 1999; Lahajnar et al., 2007).

Ratios and indices derived from the monomeric distribution of amino acid are used to estimate the state of organic matter decomposition. The degradation index DI statistically evaluates relative abundances of the 14 most common proteinogenic amino acids (Dauwe et al., 1999). The data matrix used for a principal component analysis was the amino acid composition of 28 samples, representing a wide range of environmental settings and degradation states from living plankton to Pleistocene sediments. First axis factor scores derived from this analysis were taken as the DI (Dauwe et al., 1999). To apply this index to our datasets, the molar percentages of individual amino acids were inserted as $\operatorname{var}_{i}$ into the following formula:

$\mathrm{DI}=\sum_{i}\left[\frac{\operatorname{var}_{i}-\mathrm{AVG}_{\operatorname{var}_{i}}}{\mathrm{STD} \operatorname{var}_{i}}\right] \cdot$ fac.coef $_{i}$

where the deviation of the molar percentage of each amino acid from an average value (AVG) is multiplied by an individual coefficient (fac.coef). AVG, fac.coef and STD (standard deviation) are those given in the original publication (Dauwe et al., 1999). The sum of all operations yields the DI of a given sample. Typical DI values range from 2 in well preserved samples (e.g. fresh $\mathrm{OM}$ and sapropels) to -1.5 in highly degraded sediments.

\subsection{X-ray fluorescence}

Concentrations of aluminum and barium were analyzed on fused $(600 \mathrm{mg}$ of sample diluted with $3600 \mathrm{mg}$ of lithium tetraborate) discs in an automated x-ray fluorescence spectrometer MagixPRO (Panalytical) that is equipped with a $\mathrm{Rh}$ anode. Loss on ignition was determined at $110^{\circ} \mathrm{C}$ and at $1000^{\circ} \mathrm{C}$. Concentrations of major and trace elements were calculated based on a calibration against international standards. Ratios of $\mathrm{Ba} / \mathrm{Al}$ were calculated as weight ratios of the elements barium and aluminum in the samples. 
Table 3. Sediment trap moorings in the Ierapetra Deep: mean values of $\delta^{15} \mathrm{~N}, \mathrm{DI}$, TOC and total flux.

\begin{tabular}{lrrrr}
\hline Mooring & $\begin{array}{r}\delta^{15} \mathrm{~N} \\
(\%)\end{array}$ & DI & $\begin{array}{r}\text { TOC } \\
(\%)\end{array}$ & $\begin{array}{r}\text { Total flux } \\
\left(\mathrm{mg} \mathrm{m}^{-2} \mathrm{~d}^{-1}\right)\end{array}$ \\
\hline MID 01 & 2.17 & -0.21 & 2.67 & 24.64 \\
MID 02 & 1.19 & -0.01 & 2.76 & 44.38 \\
MID 03 SH & 0.90 & 0.32 & 2.50 & 178.54 \\
MID 03 DP & 0.76 & 0.21 & 2.52 & 44.27 \\
\hline
\end{tabular}

\section{Results}

\subsection{Sediment traps}

Mean fluxes of TOC and TN in the sediment traps at Ierapetra mooring MID varied between 0.57 and $0.81 \mathrm{mg} \mathrm{m}^{-2} \mathrm{~d}^{-1}$ TOC ( 0.06 to $0.08 \mathrm{mg} \mathrm{m}^{-2} \mathrm{~d}^{-1} \mathrm{TN}$ ) in the deep traps and $3.57 \mathrm{mg} \mathrm{m}^{-2} \mathrm{~d}^{-1}$ TOC in the shallower trap $\left(0.37 \mathrm{mg} \mathrm{m}^{-2} \mathrm{~d}^{-1} \mathrm{TN}\right)$ and followed the decrease of total flux (Table 3) during particle sinking in the water column. Interestingly, $\delta^{15} \mathrm{~N}$, TOC contents and DI are similar in both the deep trap and the shallower trap during MID 03. Mean values of $\delta^{15} \mathrm{~N}$ in SPN are between 0.76 and $2.17 \%$ (Table 3) while TOC contents and DI range from 2.50 to $2.76 \%$ and from -0.21 to 0.32 , respectively. All parameters analyzed had no pronounced and no recurrent seasonality.

\subsection{Surface sediments}

The $\delta^{15} \mathrm{~N}$ values of surface sediments are between 3.5 and $5.0 \%$ (Fig. 1, Table 4) and thus are significantly enriched over the sinking material intercepted by the sediment traps. However, the general level of $\delta^{15} \mathrm{~N}$ is low in comparison to values reported for other surface sediments overlain by oxygenated deep waters (Holmes et al., 1996, 1997; Gaye-Haake et al., 2005). Low TOC contents (0.26 to $0.75 \%)$ and poor preservation reflected by DI values that range from -0.99 to 0.47 are characteristic for the hemipelagic, well oxygenated open marine sediments of the EMS.

\subsection{Downcore variations}

The insert in Fig. 2 displays DI and $\delta^{15} \mathrm{~N}$ in the upper $10 \mathrm{~cm}$ of two multicores retrieved from the Ierapetra Deep close to the trap location. Both cores show a downward increase in $\delta^{15} \mathrm{~N}$, which is most pronounced in the uppermost $1.5 \mathrm{~cm}$ (MC 284 from 2.3 to $4.8 \%$; MC 285 from 3.5 to $4.6 \%$ ) and which goes in concert with an increase in amino acid degradation. Downcore plots of analytical results for multicore \#569 from Eratosthenes Seamount in the eastern Levantine Basin that includes the $\mathrm{S} 1$ are shown in Fig. 3a. The TOC content ranges from 1.2 to $2.0 \%$ between 22 and $30 \mathrm{~cm}$ core depth and indicates the extant sapropel S1 (dark shaded).
Table 4. $\delta^{15} \mathrm{~N}$, DI and TOC values of recent surface sediments ( 0 to $1 \mathrm{~cm})$ as well as from S1, S5 and S6 sapropel interval $\left({ }^{1}=\right.$ estimated values; ${ }^{2}=$ mean values of entire sapropel).

\begin{tabular}{|c|c|c|c|c|}
\hline Core & Time equivalent & $\begin{array}{r}\delta^{15} \mathrm{~N} \\
(\% o)\end{array}$ & DI & $\begin{array}{l}\text { TOC } \\
(\%)\end{array}$ \\
\hline \# 562 & & 5.00 & -0.47 & 0.26 \\
\hline \# 563 & & 4.50 & -0.71 & 0.40 \\
\hline \# 569 & & 3.50 & -0.48 & 0.36 \\
\hline SL 152 & recent surface & 4.30 & -0.99 & 0.75 \\
\hline SL 67 & sediments & 4.40 & -0.79 & 0.44 \\
\hline SL 71 & & 5.00 & -0.64 & 0.45 \\
\hline NS 14 & & $3.90^{1}$ & n.a. & n.a. \\
\hline AD 91-17 & & $4.30^{1}$ & n.a. & n.a. \\
\hline \# 562 & & 1.74 & 0.62 & 1.74 \\
\hline \# 563 & & 0.52 & n.a. & 1.94 \\
\hline \# 569 & & 1.34 & 0.70 & 1.64 \\
\hline SL 152 & S1 sapropel ${ }^{2}$ & 2.81 & 0.24 & 1.37 \\
\hline SL 67 & & 1.25 & n.a. & n.a. \\
\hline SL 71 & & 1.57 & 0.96 & 2.29 \\
\hline NS 14 & & 2.3 & 0.46 & 0.86 \\
\hline AD 91-17 & & 3.56 & n.a. & n.a. \\
\hline SL 71 & S5 sapropel ${ }^{2}$ & -1.01 & 2.33 & 7.11 \\
\hline ODP 971C & & -0.69 & 2.43 & 4.47 \\
\hline SL 71 & S6 sapropel ${ }^{2}$ & 0.17 & 2.00 & 2.8 \\
\hline
\end{tabular}

Above S1, TOC contents range from 0.18 to $0.37 \%$, below S1 we measured 0.58 to $0.76 \%$ in the so-called protosapropel (McCoy, 1974; Anastasakis and Stanley, 1984). A high $\mathrm{Ba} / \mathrm{Al}$ ratio (seen as the strongest argument for elevated productivity during S1 formation) (Thomson et al., 1999), outlines the original extent of the sapropel in a bell-shaped maximum centered at $22 \mathrm{~cm}$. In the interval from $13-22 \mathrm{~cm}$ core depth, divergence of $\mathrm{Ba} / \mathrm{Al}$ and TOC curves marks the burndown zone above the visible S1 (light shaded), where downward progression of oxygen eradicated the high TOC concentrations, but did not affect $\mathrm{Ba} / \mathrm{Al}$ (Thomson et al., 1995). The DI curve follows that of TOC contents and displays a well preserved sapropel ( $\mathrm{DI}=0.4$ to 0.9 ); $\mathrm{OM}$ is highly degraded above the sapropel and especially so in the burndown zone $(-1.7$ to -0.5$)$. In the protosapropel, organic matter is less preserved than in the sapropel directly above (DI $=-0.2$ to -0.1$)$. The $\delta^{15} \mathrm{~N}$ pattern is a mirror image of TOC and DI curves with values between 4 and $5 \%$ above the sapropel (an exception is the low value of $3.5 \%$ of surface sediment), relatively light $\delta^{15} \mathrm{~N}$ (0.6 to $2 \%$ o) in the sapropel, and intermediate values (2.6 to $3.3 \%$ ) in the proto-sapropel. Cores \#562 and \#563 (Fig. 3b and c) show more or less the same patterns in TOC, $\delta^{15} \mathrm{~N}$ and $\mathrm{Ba} / \mathrm{Al}$ as core \#569 and confirm it as typical examples of sapropel S1.

Mean values of $\delta^{15} \mathrm{~N}$, DI, TOC for the $\mathrm{S} 1$ sapropel at the eight locations examined and for the recent surface sediments at these sites are listed in Table 4 (see Table 2 for locations 


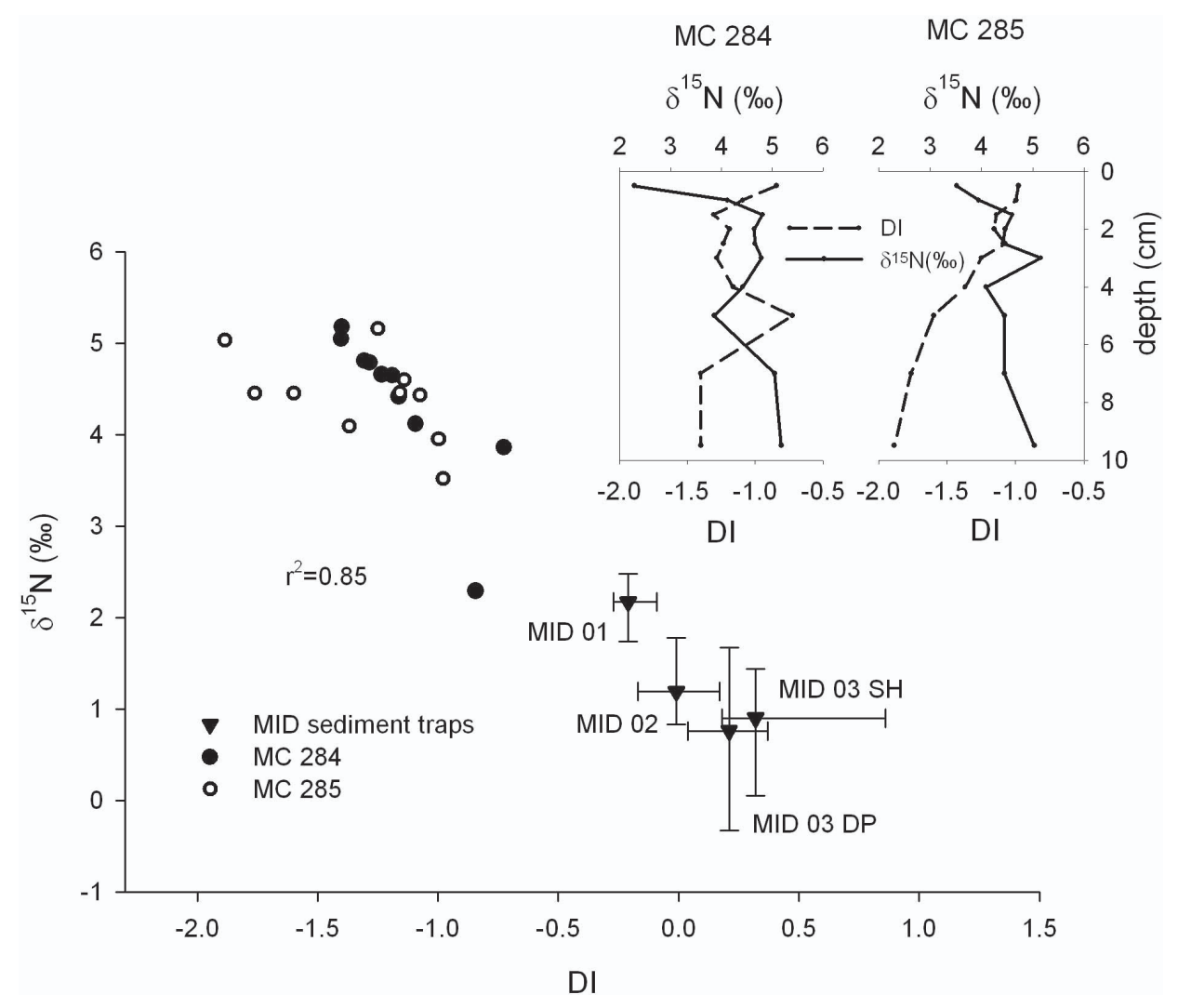

Fig. 2. $\delta^{15} \mathrm{~N}$ vs. degradation index (DI) in cores MC 284/285 from Ierapetra Deep and mean values from MID sediment traps. Higher DI values indicate better preservation. Insert: high resolution records of $\delta^{15} \mathrm{~N}$ and DI of multicores MC 284 and MC 285.

and water depths). Average $\delta^{15} \mathrm{~N}$ in the $\mathrm{S} 1$ range from $0.52 \%$ in core \#563 to 3.56\% in core AD 91-17. The DI indicates best preservation of amino acids in core SL 71 south of Crete (DI 0.96) and poorest preservation in SL 152 in the northern Aegean Sea (DI 0.24). TOC content in S1 ranges from an average of $0.96 \%$ in NS 14 (Aegean Sea) to $2.29 \%$ in SL 71. Unfortunately, DI and TOC data are not available for S1 in core SL 67, and DI data are lacking for cores AD 91-17 and \#563. The S5 (deposited after $127 \mathrm{ka}$ ) and S6 sapropels (deposited after 176 ka) from cores SL 71 and ODP 971 C (Table 4) have highest organic carbon concentrations (2.8 to $7.1 \%$ ) and best amino acid preservation, whereas $\delta^{15} \mathrm{~N}$ is most depleted in these two older sapropels $\left(\delta^{15} \mathrm{~N}=0.17\right.$ to $-1.01 \%$ o).

\section{Discussion}

It has been shown that the modern N-cycle of the EMS is probably not in a natural state due to anthropogenic inputs of atmospheric nitrate, which currently dominate external Ninputs (Mara et al., 2009). This reactive $\mathrm{N}$ has a $\delta^{15} \mathrm{~N}$ of approximately $-3 \%$ (Mara et al., 2009) and is very similar to diazotrophic fixed N ( -2 to $1 \%$; Minagawa and Wada, 1986) that represents a possible N source to the EMS in pre- industrial times (Sachs and Repeta, 1999). This coincidence in the $\delta^{15} \mathrm{~N}$ of the dominant $\mathrm{N}$ source is fortuitous, but it permits us to track the effects of diagenesis from the present water column to the sediment record.

\subsection{Alteration of amino acids and $\delta^{15} \mathrm{~N}$ in the water column and in surface sediments}

Enrichment of $\delta^{15} \mathrm{~N}$ during sinking of particles through an oxygenated water column with increasing water depth and at oxygenated sea floors is well known from other studies. Surface sediments commonly show an enrichment of 3-4\%o over material in the oceanic mixed layer and sinking particles (Altabet and Francois, 1994; Altabet, 1996; Gaye-Haake et al., 2005). Increasing $\delta^{15} \mathrm{~N}$ together with progressive amino acid degradation in the two multicores from Ierapetra Deep (Fig. 2) illustrates an enrichment of sedimentary $\delta^{15} \mathrm{~N}$ during early diagenesis in the uppermost $\mathrm{cm}$ (which is still affected by sea water) as observed in the Eastern Atlantic (Freudenthal et al., 2001). A plot of $\delta^{15} \mathrm{~N}$ vs. DI (Fig. 2) highlights the close relationship between $\delta^{15} \mathrm{~N}$ and degradation state for sinking material (mean values and ranges from Ierapetra Deep sediment trap long term moorings MID 01-03) and sediments. The linear regression $\left(r^{2}=0.85\right)$ for the entire data set is highly significant and indicates an enrichment of 

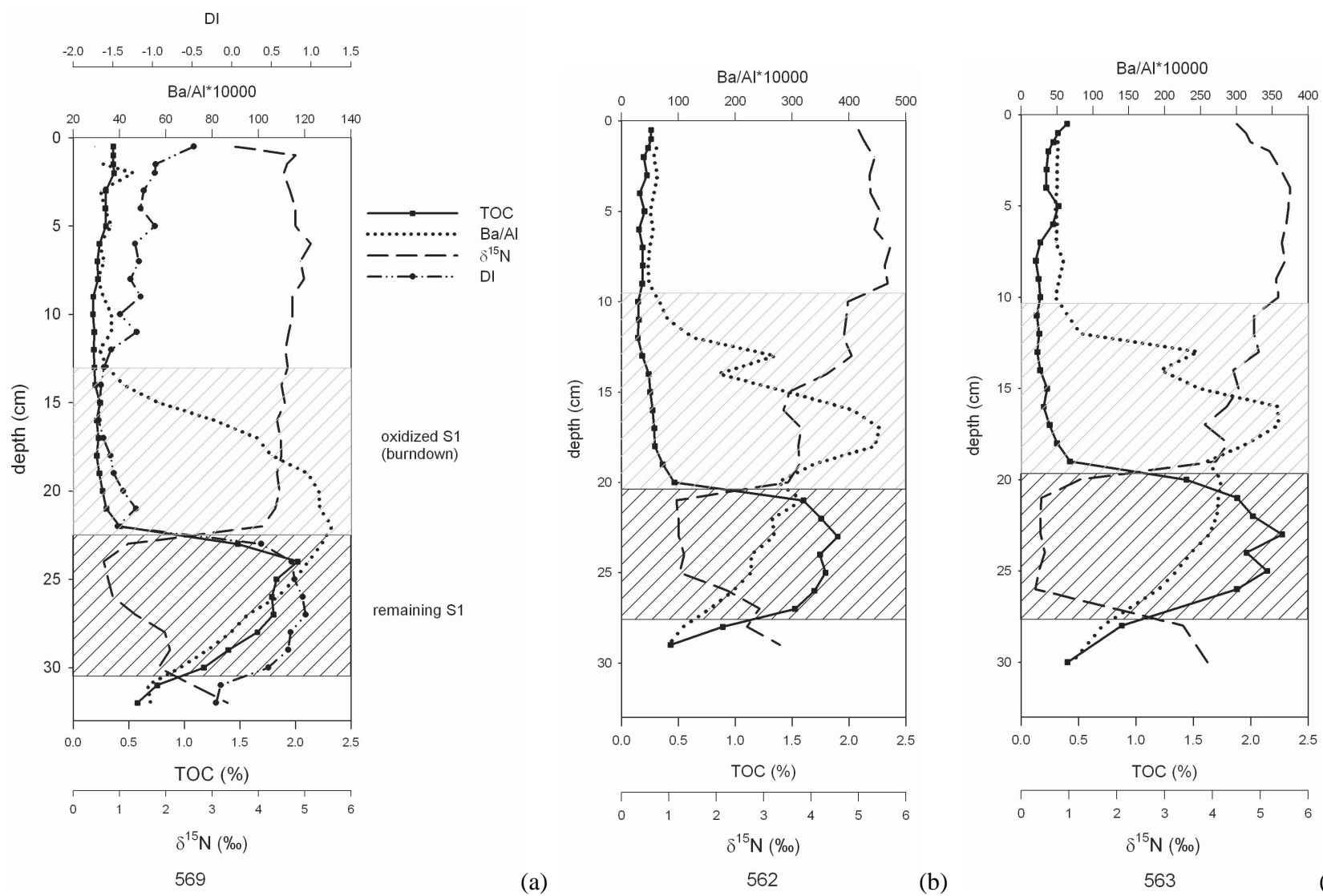

(a)

(b)

(c)

Fig. 3. Downcore plots of total organic carbon (\% TOC), barium to aluminum ratios, degradation index (DI) and $\delta^{15} \mathrm{~N}$ in multicores \#569 (a), \#562 (b) and \#563 (c). S1 sapropel intervals and the burn-down zone above S1 are marked.

3 to $4 \%$ in $\delta^{15} \mathrm{~N}$ during $\mathrm{OM}$ decomposition from the upper water column to the sediment in the modern EMS. Pronounced differences in preservation and relative OM content are not evident between the shallower and the deeper traps, contrasting with differences between traps and surface sediments. This implies that degradation during particle sinking in the water column (few days or weeks) has a much smaller effect than degradation at the oxic seafloor, where organic matter is exposed for decades and centuries due to low sedimentation and sealing rates. The observed decrease in total flux (the deep traps captured only one quarter of the material received by the shallower trap) thus reflects disaggregation and disintegration of sinking material without compoundspecific fractionation.

\subsection{The record of $\mathrm{S} 1$}

The systematic variations in OM preservation and $\delta^{15} \mathrm{~N}$ in the modern EMS help us to interpret the $\delta^{15} \mathrm{~N}$ record of core \#569 (Fig. 3a). A plot of DI versus $\delta^{15} \mathrm{~N}$ for samples from this core (Fig. 4) again indicates a highly linear relationship between the $\delta^{15} \mathrm{~N}$ and OM preservation. The well preserved and isotopically depleted sapropel S1 (core interval from 22 to $31 \mathrm{~cm}$ ) defines one end of the slope at good preservation state and low $\delta^{15} \mathrm{~N}$ that ends with strongly degraded and ${ }^{15} \mathrm{~N}$ enriched (burndown and post sapropel) sediments of the upper core section. Recent surface sediment $(0-1 \mathrm{~cm})$ and the protosapropel are moderately preserved and moderately enriched in $\delta^{15} \mathrm{~N}$. Accordingly, we attribute $\delta^{15} \mathrm{~N}$ variations in the core record to variations in OM-preservation. In this plot, average values from sediment trap material plot close to protosapropel and sapropel samples. This implies that the $\delta^{15} \mathrm{~N}$ of primary produced organic matter probably was similar during sapropel deposition as today because data from sediment traps show that relatively fresh OM sinking through the water column today has an isotopic signature similar to that of sapropels. This has already been postulated by Sachs and Repeta (1999), but possibly for the wrong reason: the $\delta^{15} \mathrm{~N}$ today is determined by atmospheric nitrate inputs, whereas the $\mathrm{S} 1$ inputs must have been through $\mathrm{N}_{2}$ fixation.

What is most important is the fact that major temporal fluctuations in the core record appear to be largely controlled by $\mathrm{OM}$ preservation (as indicated by the DI) and not by reactive $\mathrm{N}$ sources: ${ }^{15} \mathrm{~N}$ enrichment in sedimentary $\mathrm{N}$ unambiguously occurs as an enrichment of ${ }^{15} \mathrm{~N}$ in residual $\mathrm{OM}$ during progressive mineralization (ammonification) in the 


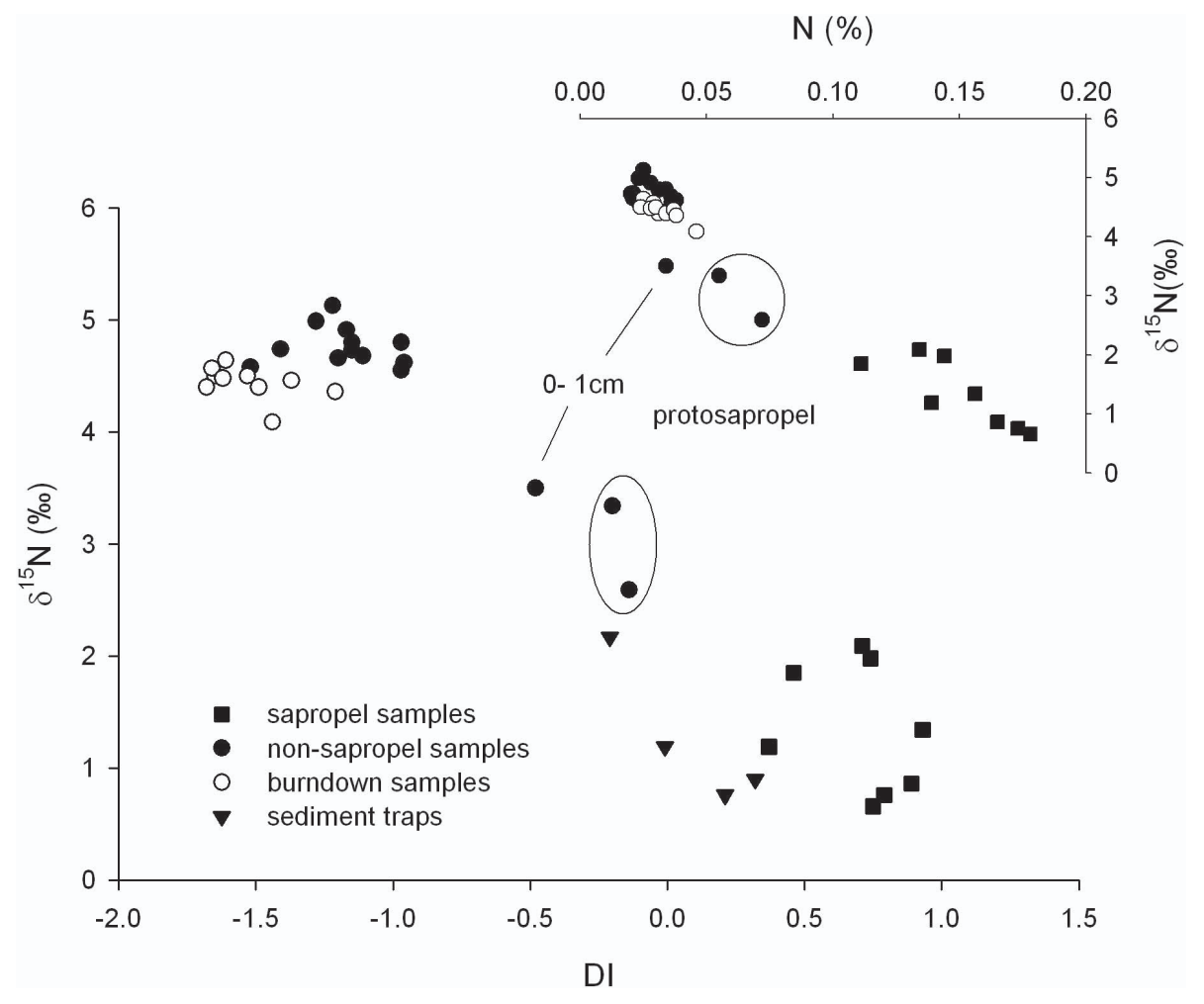

Fig. 4. Mean values of $\delta^{15} \mathrm{~N}$ vs. DI in core \#569 and mean values from MID sediment traps. Insert: $\delta^{15} \mathrm{~N}$ vs. $\mathrm{N}(\%)$ in core \#569.

sediment as shown by the insert in Fig. 4. This matches experimental evidence of changes in $\delta^{15} \mathrm{~N}$ in algal material exposed to oxic degradation (Lehmann et al., 2002). The sapropel deposited during anoxic conditions at the seafloor or in the water column below $1800 \mathrm{~m}$ water depth (de Lange et al., 2008), when decay was inhibited, retained the $\delta^{15} \mathrm{~N}$ of primary production. The protosapropel that developed under suboxic conditions or that reflects a shortened residence time under oxic conditions (due to the onset of bottom-water anoxia) is slightly degraded and slightly enriched in $\delta^{15} \mathrm{~N}$ over the sapropel base level. The $\delta^{15} \mathrm{~N}$ of the burn-down zone above the visible sapropel originally must have been equally low as in the visible sapropel but became enriched during re-oxygenation of the sediment. Interestingly, recent sinking material from sediment traps is somewhat more degraded and enriched in ${ }^{15} \mathrm{~N}$ in comparison to the material in the S1 sapropel. It may not reflect the original $\delta^{15} \mathrm{~N}$ of primary produced $\mathrm{OM}$ because the traps sampling at depths of 1508 to $2720 \mathrm{~m}$ intercept material that has already been slightly degraded and thus isotopically enriched.

Can the data help to reconstruct the $\delta^{15} \mathrm{~N}$ of primary produced OM in pre-industrial times, i.e. between the S1 sapropel and the recent sediment surface that may be contaminated with $\mathrm{NO}_{\mathrm{x}}$ ? In core \#569, the pre-industrial interval (from 1 to $13 \mathrm{~cm}$ ) has $\delta^{15} \mathrm{~N}$ values between 4 and $5 \%$. For a rough estimate of pristine values (prior to sedimentary diagenesis) we shift these data points (of highly degraded and ${ }^{15} \mathrm{~N}$ enriched sediments) onto the regression line of $\delta^{15} \mathrm{~N}$ vs. DI to DI values of well preserved OM in the sapropels or in the sediment traps, respectively (DI between 0.5 and 1.0). Accordingly, we reconstruct an original $\delta^{15} \mathrm{~N}$ of 0 to $2 \%$ in fresh sinking $\mathrm{OM}$ at that time, even though the modern atmospheric source was not yet in operation. This requires that either (1) nitrogen fixation was significant in the pre-industrial EMS or that (2) other sources with low $\delta^{15} \mathrm{~N}$, such as terrestrial/riverine $\mathrm{N}$, were the major inputs. Following the idea of Sachs and Repeta (1999), but opposed to Higgins et al. (2010), we speculate that the EMS has been N-limited since millennia, and $\mathrm{N}$-fixation occurred regardless of sapropel stages or "normal" stages until the 20th century. During the last decades, atmospheric inputs of industrial $\mathrm{NO}_{\mathrm{x}}$ replaced $\mathrm{N}$-fixation as an $\mathrm{N}$-source in a smooth transition - and the EMS became $\mathrm{P}$-limited due to excess external $\mathrm{N}$ loads. Because $\mathrm{N}$-fixation and $\mathrm{NO}_{\mathrm{x}}$ both result in $\delta^{15} \mathrm{~N}$ depleted $\mathrm{OM}$, the transition is not visible in the core record. One could argue that downcore enrichment in ${ }^{15} \mathrm{~N}$ in several EMS core tops (MC 284, MC 285, \#562, \#563 and \#569) reflects the transition to the more depleted source of reactive N. However, the simultaneous increase of amino acid degradation strongly suggests that the enrichment must be due to diagenesis.

Remaining bulk sedimentary $\mathrm{N}$ in highly degraded sediments represents only a small fraction of the original primary produced $\mathrm{N}$. Hence, our reconstructed preindustrial $\delta^{15} \mathrm{~N}$ values may be only one (but in our opinion convincing) 
of many possible solutions. Counter arguments are that little variability in DI and $\delta^{15} \mathrm{~N}$ may reflect differences in sources and that clay bound ammonia is not considered separately. Nevertheless, our hindcast matches inferences made by Sachs and Repeta (1999) based on unaltered chlorin $\delta^{15} \mathrm{~N}$ and is supported by the unambiguous post-depositional relative enrichment of ${ }^{15} \mathrm{~N}$ in the burndown zone, as well as by the strong linear relationship of total $\mathrm{N}$ content and $\delta^{15} \mathrm{~N}$.

\subsection{Spatial gradients during the S1 sapropel time slice}

Comparing the mean values of $\delta^{15} \mathrm{~N}$ in $\mathrm{S} 1$ sapropels at eight locations in the EMS (Table 4) shows that $\delta^{15} \mathrm{~N}$ is not spatially homogeneous during the S1 sapropel timeslice; this is in contrast with records for S5 (Struck et al., 2001) that all originated from deep basins. Five cores from the Levantine Basin and the Ionian Sea (M40-4 67, M40-4 71 and M51-3 562, 563 and 569) are relatively more depleted in ${ }^{15} \mathrm{~N}$ compared to nearshore locations in the Adriatic and in the Aegean Sea (AD 91-17, NS 14 and SL 152). In line with the hypotheses formulated above, we also attribute this gradient to preservational effects: the Aegean Sea was suboxic, but not anoxic, during S1 deposition, as indicated by benthic foraminiferal assemblages and abundances (Kuhnt et al., 2007). Somewhat higher $\delta^{15} \mathrm{~N}$, less well preserved amino acids, and lower TOC contents than in S1 from the deep basins probably result from stronger degradation during particle settling through the suboxic water column and at the suboxic seafloor. Although the temporary absence of benthic foraminifers in core AD 91-17 implies an anoxic seafloor at S1 time (Giunta et al., 2003), we to some extent also attribute higher $\delta^{15} \mathrm{~N}$ values to diagenetic enrichment. Shortscale (annual) variability in oxygenation may not be reflected in the abundances of benthic foraminifera, because benthic fauna requires time to recolonize the substrate after the cessation of anoxia.

Average $\delta^{15} \mathrm{~N}$ and DI values of samples from the S1 time slice (insert Fig. 5) follow the same linear relationship between OM preservation and nitrogen isotope composition as was found for recent samples from Ierapetra Deep (MC 284, MC 285, MID 01-03) and the paleo record from Eratosthenes Seamount (M51-3 \#569). But even if the trend is highly linear, some influence of different nitrate sources/utilization may be present: extremely ${ }^{15} \mathrm{~N}$ depleted $\mathrm{OM}$ in cores from the deep basins may have been contributed mainly by nitrogen fixing cyanobacteria, whereas locations closer to land may have been more influenced by terrestrial/riverine $\mathrm{OM}$ inputs that are somewhat less depleted in ${ }^{15} \mathrm{~N}$ (0 to 4\%o; Mayer et al., 2002; Voss et al., 2006). Possibly due to the dominant atmospheric source today, recent Eastern Mediterranean surface sediments display a more or less homogeneous pattern in $\delta^{15} \mathrm{~N}$ without pronounced gradients from open marine to nearshore environments or from north to south (see Fig. 1).

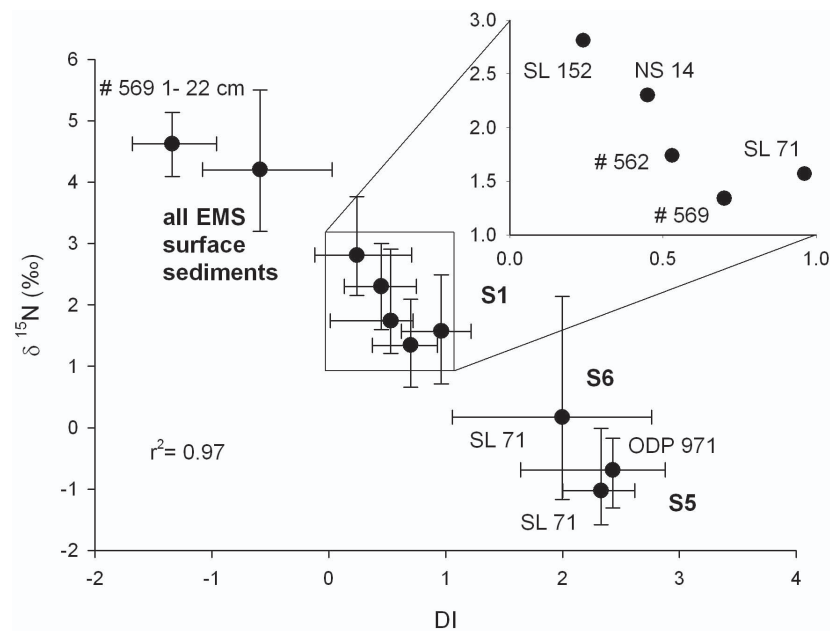

Fig. 5. Mean values of $\delta^{15} \mathrm{~N}$ vs. DI for S1, S5 and S6 sapropels, core \#569 and all Eastern Mediterranean surface samples.

\subsection{The S5 and S6 sapropel}

The older sapropels S6 and in particular the S5 have even higher organic carbon contents, better preservation of amino acids, lower $\delta^{15} \mathrm{~N}$ values, and greater thickness than the S1 sapropel, and $\delta^{15} \mathrm{~N}$ and DI for these layers in cores ODP $971 \mathrm{C}$ and SL 71 extend the linear relationship between preservation and $\delta^{15} \mathrm{~N}$ (Fig. 5). This implies a similar isotopic signature of primary produced PN for all sapropels as suggested by Sachs and Repeta (1999). As in surface sediments and S1, the differences between the sapropels must be due to differences in organic matter preservation that may have been caused by variable degrees of sediment/water column oxygenation during deposition: the depth of the oxycline and hence the oxygen exposure time of the sinking material have been variable for each sapropel interval as indicated by biomarker records. For the S5 sapropel (which has best preservation and lowest $\delta^{15} \mathrm{~N}$ ), molecular fossils of anaerobic, photolithotrophic green sulphur bacteria (Chlorobiacieae) evidence a relatively shallow oxic/anoxic interface at 150 to $300 \mathrm{~m}$ water depth (Rohling et al., 2006), whereas during $\mathrm{S} 1$ sapropel deposition the interface has been at $\sim 1800 \mathrm{~m}$ (de Lange et al., 2008). An unresolved question in this context arises from our sediment trap studies (see Sect. 4.1), because the transit through the water column apparently has no, or only a minor, effect on the isotopic composition of sinking PN in the modern situation. Hence, we speculate that either the mode of transport from the euphotic zone through the partly oxygenated water column at S1 time differed from the rapid (at an average rate of $200 \mathrm{~m} \mathrm{~d}^{-1}$ from the flux patterns intercepted by the two traps) transit today. In addition other processes may have affected OM-degradation and concomitant ${ }^{15} \mathrm{~N}$-enrichment at $\mathrm{S} 1$ time (see Sect. 4.5.) 


\subsection{Alternative explanations for ${ }^{15} \mathrm{~N}$ depletion in sapropels}

The negative $\delta^{15} \mathrm{~N}$ in $\mathrm{S} 5$ is unusual even if $\mathrm{N}_{2}$-fixation and/or incomplete nitrate utilization occurred, and we speculate that another source of isotopically light nitrogen may have contributed to sedimentary N: recent studies in the Black Sea, which is permanently anoxic at depth and thus may be a suitable analogue for the S5 situation in the EMS, revealed that appreciable amounts of depleted particulate $\mathrm{N}$ must be produced by chemoautotrophic bacteria at the transition from suboxic to anoxic waters (Fry et al., 1991; Coban-Yildiz et al., 2006). This production is sustained by either assimilation of ammonia (Fry et al., 1991; Coban-Yildiz et al., 2006) or may derive from chemoautotrophic fixation of $\mathrm{N}_{2}$ (McCarthy et al., 2007; Fuchsman et al., 2008) and $\mathrm{N}_{2} \mathrm{O}$ (Westley et al., 2006) that has been released by denitrification or anammox. Water column profiles of suspended organic $\delta^{15} \mathrm{~N}$ (SPON) (Coban-Yildiz et al., 2006) show a slight enrichment from ca. $4 \%$ in the upper mixed layer to up to $8 \%$ at the oxycline, as expected during early stages of OM decomposition in an oxygenated water column. Below the oxycline in the Black Sea, however, $\delta^{15} \mathrm{~N}$ values shift dramatically to extremely depleted values $(-8 \%)$ at the top of the anoxic water body. A simultaneous increase in the mass of total SPON implies that ${ }^{15} \mathrm{~N}$-depleted OM must be newly produced. This was attributed to newly produced OM by the biomass of chemoautotrophic bacteria utilizing $\mathrm{NH}_{4}^{+}$as their dominant $\mathrm{N}$ source (Coban-Yildiz et al., 2006). Estimated fractionation factors for bacterial ammonia assimilation are between 11 and 14\%o (Hoch et al., 1992; Voss et al., 1997), explaining the extremely low $\delta^{15} \mathrm{~N}$ values of bacterial biomass.

A second mechanism leading to negative $\delta^{15} \mathrm{~N}$ in S5 may have been the fixation of ${ }^{15} \mathrm{~N}$ depleted $\mathrm{N}_{2}$ and $\mathrm{N}_{2} \mathrm{O}$ that was released by denitrification and anammox. An unusual isotopomeric composition of $\mathrm{N}_{2} \mathrm{O}$ in the suboxic zone of the Black Sea suggested that there has been consumption and hence assimilation of depleted N (Westley et al., 2006), and $\mathrm{N}_{2}$ fixation has been observed in samples from the suboxic water layer during incubation experiments (McCarthy et al., 2007).

Considering the recent Black Sea as an analog of the EMS in its sapropel mode (i.e. anoxic deepwater, stratification, reduced surface water salinity, low ${ }^{15} \mathrm{~N}$ values, TOC-rich sediments), it appears plausible that similar processes also occurred at the redox boundary in mid-water during sapropel $\mathrm{S} 5$ formation. The extremely low ${ }^{15} \mathrm{~N}$ values in the $\mathrm{S} 5$ sapropel and as low as $-5 \%$ in older Pliocene sapropels (Arnaboldi and Meyers, 2006) are difficult to explain by either $\mathrm{N}_{2}$-fixation from cyanobacteria or by the preferential uptake of ${ }^{14} \mathrm{~N}^{-\mathrm{NO}_{3}^{-}}$as a result of $\mathrm{NO}_{3}^{-}$excess alone, but instead suggest a highly fractionating N-pathway such as chemoautotrophic $\mathrm{NH}_{4}^{+}$assimilation. The unusually low $\delta^{15} \mathrm{~N}$ values and the excellent preservation of amino acids in the S5 sapropel thus may reflect primary produced OM that has been formed directly at the redox boundary and that has never or only shortly been exposed to oxygenated water.

Interestingly, $\delta^{15} \mathrm{~N}$ values of recent deep Black Sea sediments (2-3\%o; Reschke, 1999) are in the high range of Mediterranean sapropels ( -5 to $3 \%$ ). The reason may lie in the fact that main sources of bioavailable $\mathrm{N}$ in the Black Sea are terrestrial and riverine inputs (McCarthy et al., 2007), whereas fixation of atmospheric $\mathrm{N}_{2}$ probably was the main $\mathrm{N}$-source during times of sapropel formation in the Mediterranean Sea.

\subsection{Higher than modern productivity during S1 deposition?}

There is a long-standing debate on whether TOC enrichment in Mediterranean sapropels may be solely due to better preservation under anoxic deepwater conditions, or whether it requires enhanced primary production (Howell and Thunell, 1992; Cheddadi and Rossignol-Strick, 1995). When comparing reconstructed TOC accumulation rates in the S1 sapropel with TOC fluxes in the sediment traps, we found that the modern flux rates would indeed suffice to produce a sapropel under appropriate preservation conditions: sediment traps recorded a TOC-flux of 207 to $294 \mathrm{mg} \mathrm{m}^{-2} \mathrm{y}^{-1}$ in the deeper traps (at $\sim 2600 \mathrm{~m}$ ), and $1300 \mathrm{mg} \mathrm{m}^{-2} \mathrm{y}^{-1}$ in the shallow trap $(1500 \mathrm{~m})$. On the other hand, the TOC accumulation rate for the S1 sapropel of core \#569 (1300 m) is roughly $450 \mathrm{mg} \mathrm{m}^{-2} \mathrm{y}^{-1}$, which agrees with accumulation rates calculated for a larger set of S1 by de Lange et al. (2008). Not only is the accumulation rate similar, but also TOC content of sinking material is in the range known from the S1 sapropel (see Tables 3 and 4) that can reach up to $4 \%$ in the Levantine Sea (Moodley et al., 2005). The EMS was suboxic in waters deeper than $400 \mathrm{~m}$ (Anastasakis and Stanley, 1986) and anoxic below $1800 \mathrm{~m}$ during S1 time (de Lange et al., 2008). Assuming a distinctly reduced or even inhibited decay of OM under anoxic conditions, and considering that $\mathrm{OM}$ in the traps has been already degraded during passage through the oxic water column, present-day export production in the EMS would suffice to create the $\mathrm{S} 1$ sapropel of the correct $\delta^{15} \mathrm{~N}$.

Enhanced primary productivity during $\mathrm{S} 1$ has mainly been inferred from elevated $\mathrm{Ba} / \mathrm{Al}$ ratios (Thomson et al., 1999; de Lange et al., 2008), whereby the formation and enrichment of barite crystals occurs in predominantly siliceous detritus during particle sinking through the water column (Bishop, 1988; Dymond et al., 1992; Francois et al., 1995), and newly formed barite crystals are imbedded in a matrix of organic particles. In line with our findings concerning $\delta^{15} \mathrm{~N}$ and TOC we consider it possible that the accumulation of biogenic barium in sapropels may also be controlled by OM preservation. During particle disaggregation, intense OM remineralization and cell lysis during particle sinking in the water column under normal oligotrophic conditions, barite crystals become exposed to and dissolve in sea water (Dehairs et al., 1980, 
1990). This affects more than $70 \%$ of the particulate $\mathrm{Ba}$ flux in the recent Southern Atlantic Ocean (Dehairs et al., 1980). On the other hand, if OM is less degraded and remineralized during passage through a suboxic or anoxic water column where OM decay is inhibited, barite is shielded in more or less intact detritus and accumulates in higher relative amounts in the sediments. This may have been the case during Mediterranean sapropel formation and may explain the high $\mathrm{Ba}$ contents without the need of enhanced organic carbon flux rates.

In the oxidized upper part of S1, however, Ba concentrations are decoupled from organic carbon. Whereas OM is respired to $\mathrm{CO}_{2}$ and $\mathrm{NH}_{4}$ during diagenesis, elevated barium concentrations remain as a relatively inert trace of former OM rich layers (Thomson et al., 1995) that outline the original extent of sapropels.

\section{Conclusions}

We have shown that variations of $\delta^{15} \mathrm{~N}$ in the Eastern Mediterranean sediment records are closely tied to OM preservation and do not reflect the isotopic composition of the reactive nitrogen source or differences in nitrate utilization. Our data corroborate earlier findings (Sachs and Repeta, 1999) that diazotrophic nitrogen fixation very likely has been the dominant $\mathrm{N}$ source at least during the Holocene and probably since the Pleistocene - regardless of whether the Mediterranean Sea was in sapropel or non-sapropel mode. This interpretation is at odds with a recent publication (Higgins et al., 2010) that on the basis of comparisons between bulk sediment and chlorin $\delta^{15} \mathrm{~N}$ postulates diazotrophy only for sapropel periods. Spatial patterns in $\delta^{15} \mathrm{~N}$ of S1 can also be attributed to variable degrees of OM preservation due to differences in water column oxygenation at different sites. TOC accumulation rates in long-term sediment trap moorings from the EMS are the same as those calculated for sapropel S1, so that present day primary production levels would be sufficient to create a $\mathrm{S} 1$ analog under conditions of deep water anoxia. The strongest argument for elevated organic carbon export fluxes from the ocean surface during sapropel times are elevated $\mathrm{Ba} / \mathrm{Al}$ records, which also may be affected by water column oxygenation.

Acknowledgements. This work was part of the MERF project (Marine Ecosystem Response to Fertilization) in the framework of EuroCLIMATE and was funded by the ESF and the DFG under contract Em 37/20; the manuscript was completed under partial funding of DFG special research programme INTERDYNAMIK (SPP1266). We acknowledge fruitful discussions with G. Schmiedl, B. Gaye, A. Neumann and M. Krom. U. Struck, M. Metzke and F. Langenberg are thanked for $\delta^{15} \mathrm{~N}$ analyses and sample preparation. C. Warnken is acknowledged for initial studies on the Ierapetra Deep samples. The reviewers F. Jorissen, J. Sachs and M. Krom as well as the editor S. W. A. Naqvi are thanked for their very constructive and helpful comments and suggestions.

Edited by: S. W. A. Naqvi

\section{References}

Altabet, M. A.: Variations in nitrogen isotopic composition between sinking and suspended particles: implications for nitrogen cycling and particle transformation in the open ocean, Deep-Sea Res. Pt. I, 35, 535-554, 1988.

Altabet, M. A.: Nitrogen and carbon isotopic tracers of the source and transformation of particles in the deep-sea, in: Particle Flux in the Ocean, edited by: Ittekkot, V., Schafer, P., Honjo, S., and Depetris, P. J., Wiley London, 155-184, 1996.

Altabet, M. A.: Constraints on oceanic $\mathrm{N}$ balance/imbalance from sedimentary ${ }^{15} \mathrm{~N}$ records, Biogeosciences, 4, 75-86, doi:10.5194/bg-4-75-2007, 2007.

Altabet, M. A. and Francois, R.: Sedimentary Nitrogen Isotopic Ratio as a Recorder for Surface Ocean Nitrate Utilization, Global Biogeochem. Cy., 8, 103-116, 1994.

Anastasakis, G. C. and Stanley, D. J.: Sapropels and organic-rich variants in the Mediterranean: sequence development and classification, in: Fine-grained Sediments: Deep-water Processes and Facies, edited by: Stow, D. A. W. and Piper, D. J. W., Geological Society London, 497-510, 1984.

Anastasakis, G. C. and Stanley, D. J.: Uppermost Sapropel, Eastern Mediterranean - Paleoceanography and Stagnation, Natl. Geogr. Res., 2, 179-197, 1986.

Arnaboldi, M. and Meyers, P. A.: Patterns of organic carbon and nitrogen isotopic compositions of latest Pliocene sapropels from six locations across the Mediterranean Sea, Palaeogeogr. Palaeocl., 235, 149-167, 2006.

Bada, J. L., Schoeninger, M. J., and Schimmelmann, A.: Isotopic Fractionation During Peptide-Bond Hydrolysis, Geochim. Cosmochim. Ac., 53, 3337-3341, 1989.

Bethoux, J. P.: Oxygen-Consumption, New Production, Vertical Advection and Environmental Evolution in the MediterraneanSea, Deep-Sea Res. Pt. I, 36, 769-781, 1989.

Bishop, J. K. B.: The barite-opal-organic carbon association in oceanic particulate matter, Nature, 332, 341-343, 1988.

Calvert, S. E., Nielsen, B., and Fontugne, M. R.: Evidence from nitrogen isotope ratios for enhanced productivity during formation of Eastern Mediterranean sapropels, Nature, 359, 223-225, 1992.

Cheddadi, R. and Rossignol-Strick, M.: Eastern Mediterranean Quaternary Paleoclimates from Pollen and Isotope Records of Marine Cores in the Nile Cone Area, Paleoceanography, 10, 291300, 1995.

Coban-Yildiz, Y., Altabet, M. A., Yilmaz, A., and Tugrul, S.: Carbon and nitrogen isotopic ratios of suspended particulate organic matter (SPOM) in the Black Sea water column, Deep-Sea Res. Pt. II, 53, 1875-1892, 2006.

Dähnke, K., Serna, A., Blanz, T., and Emeis, K. C.: Sub-recent nitrogen-isotope trends in sediments from Skagerrak (North sea) and Kattegat: Changes in N-budgets and N-sources?, Mar. Geol., 253, 92-98, 2008

Dauwe, B., Middelburg, J. J., Herman, P. M. J., and Heip, C. H. R.: Linking diagenetic alteration of aminoacids and bulk organic matter reactivity, Limnol. Oceanogr., 44, 1809-1814, 1999.

De Lange, G. J., Thomson, J., Reitz, A., Slomp, C. P., Principato, M. S., Erba, E., and Corselli, C.: Synchronous basin-wide formation and redox-controlled preservation of a Mediterranean sapropel, Nat. Geosci., 1, 606-610, doi:10.1038/ngeo283, 2008. 
Dehairs, F., Chesselet, R., and Jedwab, J.: Discrete suspended particles of barite and the barium cycle in the open ocean, Earth Planet. Sc. Lett., 49, 528-550, 1980.

Dehairs, F., Goeyens, L., Stroobants, N., Bernard, P., Goyet, C., Poisson, A., and Chesselet, R.: On Suspended Barite and the Oxygen Minimum in the Southern Ocean, Global Biogeochem. Cy., 40, 85-102, 1990.

Dymond, J., Suess, E., and Lyle, M.: Barium in deep-sea sediments: A geochemical proxy for paleoproductivity, Paleoceanography, 7, 163-181, 1992.

Emeis, K. C. and Weissert, H.: Tethyan-Mediterranean organic carbon-rich sediments from Mesozoic black shales to sapropels, Sedimentology, 56, 247-266, 2009.

Emeis, K.-C., Robertson, A. H. F., and Richter, C. (Eds.): Proceedings of the Ocean Drilling Program, Initial Reports 160, Ocean Drilling Program, College Station, TX, 972 pp., 1996.

Emeis, K.-C., Struck, U., Schulz, H.-M., Rosenberg, R., Bernasconi, S., Erlenkeuser, H., Sakamoto, T., and MartinezRuiz, F.: Temperature and salinity variations of Mediterranean Sea surface waters over the last 16000 years from records of planktonic stable oxygen isotopes and alkenone unsaturation ratios, Palaeogeogr. Palaeocl., 158, 259-280, 2000.

Farrell, G., Pedersen, T. F., Calvert, S. E., and Nielsen, B.: Glacialinterglacial changes in nutrient utilization in the equatorial $\mathrm{Pa}$ cific Ocean, Nature, 377, 514-517, 1995.

Francois, R., Honjo, S., Manganini, S. J., and Ravizza, G. E.: Biogenic Barium Fluxes to the Deep-Sea - Implications for Paleoproductivity Reconstruction, Global Biogeochem. Cy., 9, 289303, 1995.

Freudenthal, T., Wagner, T., Wenzhöfer, F., Zabel, M., and Wefer, G.: Early diagenesis of organic matter from sediments of the eastern subtropical Atlantic: evidence from stable nitrogen and carbon isotopes, Geochim. Cosmochim. Ac., 65, 1795-1808, 2001.

Fry, B.: Stable Isotope Ecology, Springer-Verlag, Berlin, 308 pp., 2007.

Fry, B., Jannasch, H. W., Molyneaux, S. J., Wirsen, C. O., Muramoto, J. A., and King, S.: Stable Isotope Studies of the Carbon, Nitrogen and Sulfur Cycles in the Black-Sea and the Cariaco Trench, Deep-Sea Res. Pt. I, 38, 1003-1019, 1991.

Fuchsman, C. A., Murray, J. W., and Konovalov, S. K.: Concentration and natural stable isotope profiles of nitrogen species in the Black Sea, Mar. Chem., 111, 90-105, 2008.

Ganeshram, R. S., Pedersen, T. F., Calvert, S. E., and Francois, R.: Reduced nitrogen fixation in the glacial ocean inferred from changes in marine nitrogen and phosphorus inventories, Nature, 415, 156-159, 2002.

Garvin, J., Buick, R., Anbar, A. D., Arnold, G. L., and Kaufman, A. J.: Isotopic Evidence for an Aerobic Nitrogen Cycle in the Latest Archean, Science, 323, 1045-1048, 2009.

Gaye-Haake, B., Lahajnar, N., Emeis, K. C., Unger, D., Rixen, T., Suthhof, A., Ramaswamy, V., Schulz, H., Paropkari, A. L., Guptha, M. V. S., and Ittekkot, V.: Stable nitrogen isotopic ratios of sinking particles and sediments from the northern Indian Ocean, Mar. Chem., 96, 243-255, 2005.

Giunta, S., Negri, A., Morigi, C., Capotondi, L., CombourieuNebout, N., Emeis, K. C., Sangiorgi, F., and Vigliotti, L.: Coccolithophorid ecostratigraphy and multi-proxy paleoceanographic reconstruction in the Southern Adriatic Sea during the last deglacial time (Core AD91-17), Palaeogeogr. Palaeocl., 190, 39-59, 2003.

Higgins, M. B., Robinson, R. S., Carter, S. J., and Pearson, A.: Evidence from chlorine isotopes for alternating nutrient regimes in the Eastern Mediterranean Sea, Earth Planet. Sc. Lett., 290, 102-107, 2010.

Hoch, M. P., Fogel, M. L., and Kirchman, D. L.: Isotope Fractionation Associated with Ammonium Uptake by a Marine Bacterium, Limnol. Oceanogr., 37, 1447-1459, 1992.

Holmes, M. E., Muller, P. J., Schneider, R. R., Segl, M., Patzold, J., and Wefer, G.: Stable nitrogen isotopes in Angola Basin surface sediments, Mar. Geol., 134, 1-12, 1996.

Holmes, M. E., Müller, P. J., Segl, M., and Wefer, G.: Reconstruction of past nutrient utilization in the eastern Angola Basin based on sedimentary 15N/14N ratios, Paleoceanography, 12(4), 604614, 1997.

Howell, M. W. and Thunell, R. C.: Organic carbon accumulation in Bannock Basin: Evaluating the role of productivity in the formation of eastern Mediterranean sapropels, Mar. Geol., 103, 461471, 1992.

Jenkyns, H. C., Grocke, D. R., and Hesselbo, S. P.: Nitrogen isotope evidence for water mass denitrification during the early Toarcian (Jurassic) oceanic anoxic event, Paleoceanography, 16, 593-603, 2001.

Jennerjahn, T. C. and Ittekkot, V.: Changes in organic matter from surface waters to continental slope sediments off the Sao Francisco River, eastern Brazil, Mar. Geol., 161, 129-140, 1999.

Jung, M., Ilmberger, J., Mangini, A., and Emeis, K. C.: Why some Mediterranean sapropels survived burn-down (and others did not), Mar. Geol., 141, 51-60, 1997.

Kemp, A. E. S., Pearce, R. B., Koizumi, I., Pike, J., and Rance, S. $\mathrm{J}$.: The role of mat-forming diatoms in the formation of Mediterranean sapropels, Nature, 398, 57-61, 1999.

Krom, M. D., Woodward, E. M. S., Herut, B., Kress, N., Carbo, P., Mantoura, R. F. C., Spyres, G., Thingstad, T. F., Wassmann, P., Wexels-Riser, C., Kitidis, V., Law, C. S., and Zodiatis, G.: Nutrient cycling in the south east Levantine basin of the eastern Mediterranean: Results from a phosphorus starved system, Deep-Sea Res. Pt. II, 52, 2879-2896, 2005.

Krom, M. D., Emeis, K. C., and Van Cappellen, P.: Why is the Eastern Mediterranean phosphorus limited?, Progr. Oceanogr., 85, 236-244, 2010.

Kuhnt, T., Schmiedl, G., Ehrmann, W., Hamann, Y., and Hemleben, C.: Deep-sea ecosystem variability of the Aegean Sea during the past $22 \mathrm{kyr}$ as revealed by Benthic Foraminifera, Mar. Micropaleontol., 64, 141-162, 2007.

Kuypers, M. M. M., van Breugel, Y., Schouten, S., Erba, E., and Damste, J. S. S.: N-2-fixing cyanobacteria supplied nutrient N for Cretaceous oceanic anoxic events, Geology, 32, 853-856, 2004.

Lahajnar, N., Wiesner, M. G., and Gaye, B.: Fluxes of amino acids and hexosamines to the deep South China Sea, Deep-Sea Res. Pt. I, 54, 2120-2144, 2007.

Lehmann, M. F., Bernasconi, S. M., Barbieri, A., and McKenzie, J. A.: Preservation of organic matter and alteration of its carbon and nitrogen isotope composition during simulated and in situ early sedimentary diagenesis, Geochim. Cosmochim. Ac., 66, 35733584, 2002. 
Macko, S. A. and Estep, M. L. F.: Microbial alteration of stable nitrogen and carbon isotopic compositions of organic matter, Org. Geochem., 6, 787-790, 1984.

Mara, P., Mihalopoulos, N., Gogou, A., Daehnke, K., Schlarbaum, T., Emeis, K. C., and Krom, M.: Isotopic composition of nitrate in wet and dry atmospheric deposition on Crete in the eastern Mediterranean Sea, Global Biogeochem. Cy., 23, GB4002, doi:10.1029/2008gb003395, 2009.

Mayer, B., Boyer, E. W., Goodale, C., Jaworski, N. A., Van Breemen, N., Howarth, R. W., Seitzinger, S., Billen, G., Lajtha, L. J., Nosal, M., and Paustian, K.: Sources of nitrate in rivers draining sixteen watersheds in the northeastern US: Isotopic constraints, Biogeochemistry, 57, 171-197, 2002.

McCarthy, J. J., Yilmaz, A., Coban-Yildiz, Y., and Nevins, J. L.: Nitrogen cycling in the offshore waters of the Black Sea, Estuar. Coast. Shelf S., 74, 493-514, 2007.

McClelland, J. W. and Valiela, I.: Linking nitrogen in estuarine producers to land-derived sources, Limnol. Oceanogr., 43, 577-585, 1998.

McCoy, F. W.: Late Quaternary sedimentation in the eastern Mediterranean Sea, Harvard University, 1974.

Mercone, D., Thomson, J., Abu-Zied, R. H., Croudace, I. W., and Rohling, E. J.: High-resolution geochemical and micropalaeontological profiling of the most recent eastern Mediterranean sapropel, Mar. Geol., 177, 25-44, 2001.

Meyers, P. A. and Bernasconi, S. M.: Carbon and nitrogen isotope excursions in mid-Pleistocene sapropels from the Tyrrhenian Basin: Evidence for climate-induced increases in microbial primary production, Mar. Geol., 220, 41-58, 2005.

Milder, J. C. and Montoya, J. P.: Carbon and nitrogen stable isotope ratios at Sites 969 and 974: interpreting spatial gradients in sapropel properties, in: Proc. ODP, Scientific Results, edited by: Zahn, R., Comas, M., and Klaus, A., Ocean Drilling Programm College Station, 161, 401-411, 1999.

Minagawa, M. and Wada, E.: Nitrogen Isotope Ratios of Red Tide Organisms in the East-China-Sea - a Characterization of Biological Nitrogen-Fixation, Mar. Chem., 19, 245-259, 1986.

Moodley, L., Middleburg, J. J., Herman, P. M. J., Soetaert, K., and de Lange, G. J.: Oxygenation and organic-matter preservation in marine sediments: Direct experimental evidence from ancient organic carbon-rich deposits, Geology, 33, 889-892, 2005.

Murat, A. and Got, H.: Organic carbon variations of the eastern Mediterranean Holocene sapropel: a key for understanding formation processes, Palaeogeogr. Palaeocl., 158, 241-257, 2000.

Pantoja, S., Repeta, D. J., Sachs, J. P., and Sigman, D. M.: Stable isotope constraints on the nitrogen cycle of the Mediterranean Sea water column, Deep-Sea Res. Pt. I, 49, 1609-1621, 2002.

Ren, H., Sigman, D., Meckler, A. N., Plessen, B., Robinson, R. S., Rosenthal, Y., and Haug, G. H.: Foraminiferal Isotope Evidence of Reduced Nitrogen Fixation in the Ice Age Atlantic Ocean, Science, 323, 244-248, 2009.

Reschke, S.: Biogeochemie der Schwebstofffracht der Donau und deren Einfluß auf das Sedimentationsgeschehen im nordwestlichen Schwarzen Meer, Ph.D thesis, Universität Hamburg, Hamburg, 109 pp., 1999.

Rohling, E. J.: Review and new aspects concerning the formation of eastern Mediterranean sapropels, Mar. Geol., 122, 1-28, 1994.

Rohling, E. J., Hopmans, E. C., and Damste, J. S. S.: Water column dynamics during the last interglacial anoxic event in the
Mediterranean (sapropel S5), Paleoceanography, 21, PA2018, doi:10.1029/2005Pa001237, 2006.

Rossignolstrick, M., Nesteroff, W., Olive, P., and Vergnaudgrazzini, C.: After the Deluge - Mediterranean Stagnation and Sapropel Formation, Nature, 295, 105-110, 1982.

Ryan, W. B. F.: Stratigraphy of Late Quarternary sediments in the eastern Mediterranean, in: The Mediterranean Sea: a Natural Sedimentation Laboratory, edited by: Stanley, D. J., Dowden, Hutchinson and Ross, Stroudsburg, Pa, 149-169, 1972.

Sachs, J. P. and Repeta, D. J.: Oligotrophy and Nitrogen Fixation During Eastern Mediterranean Sapropel Events, Science, 286, 2485-2488, 1999.

Saino, T. and Hattori, A.: N-15 Natural Abundance in Oceanic Suspended Particulate Matter, Nature, 283, 752-754, 1980.

Sigman, D. M., Altabet, M. A., Francois, R., McCorkle, D. C., and Gaillard, J. F.: The isotopic composition of diatom-bound nitrogen in Southern Ocean sediments, Paleoceanography, 14, 118134, 1999.

Silfer, J. A., Engel, M. H., and Macko, S. A.: Kinetic Fractionation of Stable Carbon and Nitrogen Isotopes During Peptide-Bond Hydrolysis - Experimental-Evidence and Geochemical Implications, Chem. Geol., 101, 211-221, 1992.

Slomp, C. P., Thomson, J., and de Lange, G. J.: Enhanced regeneration of phosphorus during formation of the most recent eastern Mediterranean sapropel (S1), Geochim. Cosmochim. Ac., 66, 1171-1184, 2002.

Struck, U., Emeis, K.-C., Voss, M., Krom, M. D., and Rau, G. H.: Biological productivity during sapropel S5 formation in the Eastern Mediterranean Sea: evidence from stable isotopes of nitrogen and carbon, Geochim. Cosmochim. Ac., 65, 3249-3266, 2001.

Thomson, J., Higgs, N. C., Wilson, T. R. S., Croudace, I. W., De Lange, G. J., and Van Santvoort, P. J. M.: Redistribution and geochemical behaviour of redox-sensitive elements around S1, the most recent eastern Mediterranean sapropel, Geochim. Cosmochim. Ac., 59, 3487-3501, 1995.

Thomson, J., Mercone, D., De Lange, G. J., and Van Santvoort, P. J. M.: Review of recent advances in the interpretation of eastern Mediterranean sapropel S1 from geochemical evidence, Mar. Geol., 153, 77-89, 1999.

Triantaphyllou, M. V., Antonarakou, A., Kouli, K., Dimiza, M., Kontakiotis, G., Papanikolaou, M. D., Ziveri, P., Mortyn, P. G., Lianou, V., Lykousis, V., and Dermitzakis, M. D.: Late GlacialHolocene ecostratigraphy of the south-eastern Aegean Sea, based on plankton and pollen assemblages, Geo-Mar. Lett., 29, 249267, doi:10.1007/s00367-009-0139-5, 2009.

Tyrrell, T.: The relative influences of nitrogen and phosphorus on oceanic primary production, Nature, 400, 525-531, 1999.

Voss, M., Nausch, G., and Montoya, J. P.: Nitrogen stable isotope dynamics in the central Baltic Sea: influence of deep-water renewal on the N-cycle changes, Mar. Ecol.-Prog. Ser., 158, 11-21, 1997.

Voss, M., Emeis, K. C., Hille, S., Neumann, T. and Dippner, J. W.: Nitrogen cycle of the Baltic Sea from an isotopic perspective, Global Biogeochem. Cy., 19, GB3001, doi:10.1029/2004GB002338, 2005.

Voss, M., Deutsch, B., Elmgren, R., Humborg, C., Kuuppo, P., Pastuszak, M., Rolff, C., and Schulte, U.: Source identification of nitrate by means of isotopic tracers in the Baltic Sea catchments, Biogeosciences, 3, 663-676, doi:10.5194/bg-3-663-2006, 2006. 
Wallmann, K.: Feedbacks between oceanic redox states and marine productivity: A model perspective focused on benthic phosphorus cycling, Global Biogeochem. Cy., 17, 1084, doi:10.1029/2002GB001968, 2003.
Westley, M. B., Yamagishi, H., Popp, B. N., and Yoshida, N.: Nitrous oxide cycling in the Black Sea inferred from stable isotope and isotopomer distributions, Deep-Sea Res. Pt. II, 53, 18021816, 2006. 